Although no direct evidence has been secured as to the origin of the outbreak of the European corn borer, this may have been due in Elgin and Middlesex counties to importations of broom corn from Europe. From correspondence, it has been learned that all Canadian broom manufacturers prefer to use broom corn grown on this continent, but in 1909-10 there was apparently a shortage of this product and one firm at least located in this district, imported large quantities of corn from Central Europe.

President Arthur Gibson: The next paper is by Messrs. Crawford and Spencer.

\title{
THE EUROPEAN CORN BORER CONTROL MEASURES
}

Joint results of studies in 1921, of H. G. CRAwFORD, Dominion Department of Entomology, Ottava, Canada, and G. J. Spencer, Ontario Agricultural College, Guelph, Canada.

Complete control measures for the European Corn Borer in Canada have not as yet been perfected. Many facts have been worked out with regard to its life history, enabling us to outline certain practices which will go a long way towards keeping it in check in the districts where it is most prevalent. The question of limiting it to these areas will be discussed later.

We know of no means of destroying the European Corn Borer in the pupal, moth or egg stages. But since it spends about ten months of the year as a larva, it is in that stage that we can best bring about its destruction.

At harvest time the borer is full grown and may be found in all parts of the corn stalk except the leaves, from the tassel down to the tap root. Standing stubble or stubble plowed out and left on the surface with debris of all sizes, and corn stalks left in stooks or in standing sheaves or lying on the ground, constitute ideal quarters for borers to winter in, with remarkably low percentage of mortality.

Control: falls under two phases-

Phase 1. The destruction of the borer in the stems and cobs of corn.

Phase 2. The destruction of the borer in the stubble and refuse on the field after the crop has been removed.

PhASE I. The destruction of the borer in the stem. By cutting the corn as low and as early as is compatible with maturity, by far the largest proportion of borers in a field can be removed in the stems. The longer the stalks are left intact, the further down the borers will work and if all are not mature but are still feeding, the more damage they do. The 
handling of the corn during harvesting operations will cause some borers to become restless and to leave the stalks. This is unavoidable.

A silo extension campaign should be strenuously waged.

The cutting box kills most of the borers; those that escape the knives are accounted for by the heat and the fermentation of the silage. A very few larvae in several inch-lengths of stalk, that have escaped the knives at filling time, walk up the sides of the silo and escape. Some escape from the stalks at cutting time, into the machine. Hens were observed to eat these greedily.

\section{Where THERE IS No Silo}

In dealing with the stalks, the handling of corn for feeding as stover and of husking corn, presents the chief problem.

The removal of stalks from the field directly after harvest so as to allow of the early plowing of the field, presents at present the greatest single difficulty in control measures.

Farmers prefer to leave the stooks in the field until dry, rather than haul them to some other field or land, to dry sufficiently to allow of their being put into the barn without moulding.

We recommend the shredding where possible of all corn stalks used as fodder. This insures many of the borers being killed and the rore complete eating of the corn by stock. The processs of shredding causes many larvae to leave their burrows and they then fall among the grain that shells out from the cobs. It was found that $80 \%$ of these were killed. When shredding is not practicable, the stalks after feeding and stalks used as bedding should not be thrown out into manure heaps as is usually done, but should be piled separately in an enclosure where the cattle cannot scatter them around, and should be burned. The fate of larvae in stalks trodden into, manure and the effectiveness of this means of dealing with waste stalks, has not yet been completely worked out. It is still under investigation and observation.

Some farmers have been in the habit of burning waste stalks every week; they claim that it gives very little extra trouble. In any case the waste pile should be burned by the end of May, before pupation commences. If corn stalks are wet and are densely piled, the larvae leave the bottom layers early in spring and migrate to the upper three inches. Where the upper surface of the pile is dry, it can be readily burned over before June. In piles of dry stalks, the larvae do not migrate to the top and will pupate in their burrows from ground level right up through the mass and the moths will all emerge. In one case, it was found that all moths had emerged from a load of stalks $4 \mathrm{ft}$. 10 inches high, from 
the very bottom of the pile. This pile being quite dry it burned completely to the ground.

Ears of corn that have been husked in the field should be hauled off with the stalks as soon after harvest as possible so as to allow of the early plowing of the field, and the waste husks should be burned.

Since this year's corn crop was so heavy (1920) several farmers in the infested districts, after filling and refilling their silos and selling what they could of the crop, burned all the rest of it in the field. Drastic measures, but very praiseworthy.

The stalks of sweet corn grown for factories should be cut after harvest, hauled off, fed and the remains treated as outlined-or if not used for feed, should be cut in the field with a mower, raked into windrows and, when thoroughly dry, burned. Some factories sell their corn stalks and cobs that were grown on contract; some ensile it as well as the cobs after being shelled at the factory, and sell the ensilage. This whole practice is to be recommended, since they may harbor larvae. Corn cobs after being shelled, should be burned (if not used as fuel) in the waste pile, rather than be left lying around the yard.

Second Phase. "The destruction of larvae remaining in stubble and crop refuse in the field after the crop has been removed."

Stubble in any position and debris on the surface and weeds growing among corn, can and do harbor larvae.

In stubble we have found as high as 11000 to 14360 larvae per acre.

In debris we have found as high as 31000 larvae per acre.

In weeds we have found as high as 24000 larvae per acre.

Stubble left standing in the field or plowed out and left lying on the surface, constitutes almost ideal sheltering conditions for over wintering larvae. It has been found impracticable to dig or plow out stubble in order to pile and burn it.

Under conditions that existed in Ontario 1920 and in the fall of 1921, "we have found that the plowing under to a depth of 6 inches, of stubble and debris, as early as possible after the removal of the crop is the factor of control second only in importance to the silo. About the middle of September is the latest safe date for plowing to work, at Port Stanley, Ont. if the larvae are to be forced to leave the stubble in largest possible numbers.

The efficiency of plowing is in direct ratio to its earliness. By the end of October, the upward migration has ceased to be of much consequence and larvae in stubble and debris, plowed under at and after that date, will remain underground through the winter without suffering heavy mortality and migrate out before the last of April the following spring. 
In dry sandy loam, bundles of stalks were buried with a larval expectation of at least fifty per bundle, and were taken and examined at intervals. The results follow:-

Date buried, Sept. 4.

Dates removed. Sept. 20 Sept. 28 Oct. 12 Oct. 25 Nov. 2 Nov. 1. $\begin{array}{lllllll}53 & 8 & 4 & 5 & 2 & 1 & \text { larvae. }\end{array}$

Plowing must be done thoroughly so as to cover all stubble and debris. This is materially helped by rolling immediately the crop is off, as rolling crushes open from $95 \%$ to $97 \%$ of the stubble, flattens down the stubble and weeds, kills some borers and destroys good wintering quarters for others, because it greatly facilitates moisture getting into the stalks and consequently, their earlier decay. Moreover, larvae leave moist soil sooner than dry soil. Under dry conditions, the whole season may be necessary to get all larvae in plowed under stubble, to come to the surface. Early plowing kills some borers but is chiefly of importance because it forces the vast majority of them to come to the surface. If any debris is around, they enter it.

On stubble land that has not been cleanly plowed down, rolling after plowing undoubtedly forces some outstanding stalks under the surface. Rolling of land that has been well and cleanly plowed, has been found undesirable because it delays the movement upwards, of the borers, and facilitates their migration to surrounding fields, when they do come up.

This movement upwards, of the larvae, is influenced by the type of soil in which infested material is buried, by temperature and by moisture. Just what these conditions are, has not been worked out yet. Reactions vary according to the time and consequently the temperature of the season.

Comparison of rates of larvae leaving various types of soil, in order of degree. Larvae used-at least 300 in each case.

\section{Soils}

1. Moist sand loam

2. Dry sand loam

3. Wet clay

4. Sand

5. Dry sand loam (single layers)

6. Dry clay
Larvae regained

$$
29
$$

41

49

54

72

106
Expectation

300

In some experiments the larvae died in material that was buried early in August. In the majority of cases, however, the earlier the plowing, the sooner the larvae emerged from the soil. This shows that in August, larvae emerged rapidly and migrated to neighbouring fields. 
In September especially on land plowed and sown to wheat, they did not migrate much to other fields, but simply disappeared. Spring plowing will kill a large number (how large a percentage is not known) but many mature. If spring plowing is done late, up to within a short time of pupation of the borers, the larvae will emerge after being plowed under. But if just ready to pupate, and then plowed down, they pupate in the stalks under ground and a high percentage of adults emerge from pupal cases, but none of them can reach the surface, from lower than 2 inches and the wings of the very few that do emerge are so battered that they cannot fly and soon perish.

The Futility of Individual isolated cases of cleaning up.

Unless a corn field is a long distance from other corn fields and is shut in by woods, the efforts of individual farmers to control the borer by thorough clean-up methods, are utterly futile. The movement must be community wide, if it is to succeed at all.

Late Planting. As has been pointed out, moths lay eggs most freely on the earliest sown and consequently the tallest, corn. Late planting of the main crop will undoubtedly reduce its degree of infestation. Some corn may have to be planted earlier to act as a catch crop, especially where very large acreages are grown in any one place in the infested regions. Trap crops may function if sown in fairly wide strips down one side of a field nearest to last years corn field. If this succeeds in attracting most of the infestation, it should be removed and fed at once and the waste parts burned when dry-or destroyed entirely if heavily infested, well before the main crop is harvested.

These control measures are not expensive to execute. Usually only one field on a farm is involved. Corn is such an important crop that the extra care necessary in thorough cleaning up operations will well repay time spent on them and any inconvenience involved.

\section{Natural Control}

NATURAL FACTORS IN THE CONTROL OF THE EUROPEAN CORN BORER.

1. Natural agencies, weather and winter, killed less than $3 \%$ of borers in winter 1920-1921.

2. In spring of 1920 , the tachina fly, Exorista nigripalpis Town, accounted for so high as $13 \%$ larvae in one field with an average of $8 \%$ for that field. For the district an average of 3 or $4 \%$ would be fairly true. It cannot yet be considered of much consequence in control.

3. The insect that probably does more good than any other, is the spotted ladybird beetle, Ceratomegilla fuscilabris (Megilla maculata) which was repeatedly seen to eat every egg mass it found. These bee- 
tles were kept in cages and were fed egg masses, which they consumed entirely. No Hymenopterous parasites were reared from larvae or eggs.

President Arthur Gibson: The final paper in the series is by Mr. E. P. Felt.

\section{THE EUROPEAN CORN BORER IN NEW YORK STATE ${ }^{1}$}

By E. P. Felt, State Entomologist, Albany, N. $Y$.

The exceptionally severe and wide spread injury by the corn ear worm, Chloridea obsoleta Fabr., has been particularly unfortunate in that it has attracted general attention to a passing phenomenon and thus in considerable measure obscured a really serious problem.

It happens that the European Corn Borer, Pyrausta nubilalis Hubn., has as yet caused relatively little damage in New York State, though there has been appreciable injury to comparatively small plantings. The development of the last few years make it impossible to be certain as to the cause for this comparative immunity. The exceptionally thorough and general clean up in the eastern infested area in the spring of 1919 presumably had an important effect upon the abundance of the borers and even yet the pest is not numerous in that section, a fifteen per-cent stalk infestation being near the maximum. This work was on an exterminative basis, consequently no checks were left.

There was in the western part of New York State a thorough clean up during the fall of 1920 and the spring of 1921 by the Federal Government in the more badly infested section, centering on Silver Creek. Examinations and comparisons the past summer showed little difference between the cleaned up areas and the conditions on the nearby Indian Reservation where a forty per-cent stalk infestation was not difficult to find. There is no question but what the clean up destroyed hosts of borers. It is possible that climatic conditions were exceptionally favorable and enabled the few remaining insects to transform and deposit a maximum number of eggs and thus offset in considerable measure the beneficent results which should follow general clean up work. It has been suggested that the operations may have been nullified to a considerable extent by moths drifting from another badly infested area. This must be considered simply as a possibility and as yet not even the probability has been established.

\footnotetext{
1Some of the data given in this paper have been secured by the writer in his capacity as Collaborator, Bureau of Entomology, U. S. Department of Agriculture.
} 